\title{
MENIKMATI KOPI, MEMAKNAI “JOSS" \\ Studi Eksploratif terhadap Pengalaman Wisatawan Domestik didalam Mengonsumsi Kopi Joss
}

\author{
Yudo Hartono \\ Universitas Prasetiya Mulya \\ Email: yudo.hart@pmbs.ac.id \\ Sri Widya Wijanarti \\ Universitas Prasetiya Mulya \\ Email: sriwidya.wijanarti@pmbs.ac.id
}

\begin{abstract}
This study aims to explore the meaning from the experience of Kopi Joss consumption from domestic tourist's perspective. Kopi Joss is a name of coffee little shop that called angkringan near Malioboro Street in Yogyakarta. In this study, Holt's Typology is used to analyze the meaning of the consumption from cultural and social perspective and this research uses qualitative perspective with domain analysis to describe the depth of the data. The result shows Kopi Joss meaning is related to the context where the consumption took place and the result can be used to strengthen the position of Kopi Joss in the future.
\end{abstract}

Keywords: Kopi Joss, Domain analysis, coffee meaning

\section{Pendahuluan}

"Kopi" dikenal sebagai istilah untuk minuman yang dihasilkan dari proses ekstraksi - melarutkan bubuk kopi panggang di dalam air mendidih. Minuman kopi bisa disiapkan dengan berbagai cara, salah satunya dengan metode filtrasi-perkolasi, dimana kopi bubuk ditempatkan pada jaringan tertentu (kertas saring, muslin, filter plastik berlubang, dan lain lain) kemudian diekstraksi dengan cara menuang atau menyemprot dengan air panas dengan perkolasi gravitasi lambat. Pada umumnya, prosedur ini digunakan di sebagian besar mesin kopi (Petracco 2001). Dalam proses ini, temperatur air yang digunakan tidak melebihi $90-95^{\circ} \mathrm{C}$ sehingga zat-zat yang 
mudah menguap dapat dipertahankan dalam minuman kopi (Belitz et al. 2009; Navarini dan Rivetti 2010).

Kopi juga merupakan salah satu minuman yang paling banyak dikonsumsi di dunia dan merupakan komoditas perdagangan terbesar kedua setelah minyak bumi (Mussatto, 2011). Negara Indonesia dikenal sebagai salah satu penghasil biji kopi terbesar ke-4 di dunia setelah Brazil, Vietnam, dan Columbia - dengan hasil produksi biji kopi sebanyak 720.000 ton per tahun dan mengekspor 38\% nya ke seluruh penjuru dunia (ICO, 2018). Berlimpahnya produksi kopi dengan berbagai macam varian dengan rasa yang luar biasa, menjadikan penduduk Indonesia termasuk dalam orangorang yang menggemari kopi. Begitu banyaknya penggemar kopi, bahkan ada beberapa orang yang merasa belum bersemangat untuk beraktivitas apabila belum mengkonsumsi minuman berwarna "gelap" dengan aroma yang kuat ini.

Di dunia terdapat 2 varietas pohon kopi yang dikenal secara umum, yaitu Arabica (Coffeea Arabica) dan Robusta (Coffeea Canephora). Perbedaan kedua jenis kopi ini terletak pada tingkat keasaman rasa kopi, kondisi tempat varietas ini bertumbuh dan cara panen biji kopinya. Indonesia memiliki iklim yang cocok bagi perkembangan produksi kopi dan banyak perkebunan kopi di wilayah Sumatera, Jawa dan Sulawesi, sehingga dikenal sebagai salah satu penghasil biji kopi terbesar di dunia. Lebih dari 1,25 juta hektar perkebunan kopi, dengan 75\% perkebunan Robusta dan 25\% perkebunan Arabika terdapat di Indonesia.

Begitu kaya variasi kopi yang tumbuh di Indonesia, bahkan ada 8 jenis kopi yang hanya terdapat di Indonesia, yaitu Kopi Luwak (dikenal sejak tahun 1980-an, biji kopinya diambil dari sisa kotoran Luwak atau Musang Kelapa), Kopi Toraja (berasal dari dataran tinggi Kabupaten Tana Toraja - Sulawesi), Kopi Lanang (berasal dari ujung timur pulau Jawa - Banyuwangi yang biji kopinya berbentuk bulat dan tidak berbelah seperti biji kopi yang umum), Kopi Kintamani (jenis kopi yang sudah memiliki GI berasal dari satu daerah di Bali yang bercita rasa asam dan segar), Kopi 
Aceh Gayo (produsen kopi arabika terbesar di Asia), Kopi Wamena (berasal dari Papua dengan tingkat keasaman yang rendah), Kopi Flores Bajawa (berasal dari Nusa Tenggara Timur yang aroma kopinya bertahan cukup lama), dan Kopi Jawa (berasal dari Tanah Jawa dan beraroma rempah).

Seiring dengan tumbuhnya arus wisatawan domestik yang dapat dilihat dari data BPS dimana tercatat pertumbuhan di tahun 2018 sekitar 12,37\% dibandingkan dengan tahun sebelumnya. Sementara belanja wisatawan domestik pada tahun 2018 juga mengalami pertumbuhan sebesar $12,89 \%$ dibandingkan dengan tahun sebelumnya. Dari informasi ini maka dapat dilihat potensi yang besar yang dimiliki oleh para wisatawan domestik ini terkait dengan pengeluarannya selama mereka melakukan perjalanan berwisata.

Meskipun bersifat asumtif, besaran pengeluaran individu secara tidak langsung juga mempengaruhi gaya hidup dimana minum kopi tidak lagi bersifat fungsional tetapi juga telah menjadi simbolik dan bermakna sosial dimana minum kopi tidak lagi sekedar terkait dengan preferensi tetapi telah menjadi pemenuhan kebutuhan yang melibatkan prestise dan gengsi. Konsumsi yang ditunjukkan inilah yang sering disebut Braudillard sebagai masyarakat konsumen.

Begitu juga dengan cara menyeduh dan penyajian kopi menjadi minuman juga banyak variasinya menjadi bagian dari pengalaman mengkonsumsi kopi itu sendiri. Salah satu jenis kopi seduh yang unik dan bahkan menjadi simbol suatu daerah adalah Kopi Arang di Yogyakarta. Keunikan Kopi Arang atau yang lebih dikenal dengan sebutan Kopi Joss ini adalah pada cara penyajiannya. Kopi Joss, disajikan dengan memasukkan arang yang masih membara (mawa, dalam bahasa lokal) ke dalam kopi seduh yang akan diminum. Suara yang ditimbulkan bara arang panas ke dalam segelas kopi itulah yang menjadi asal-usul nama "Joss". 


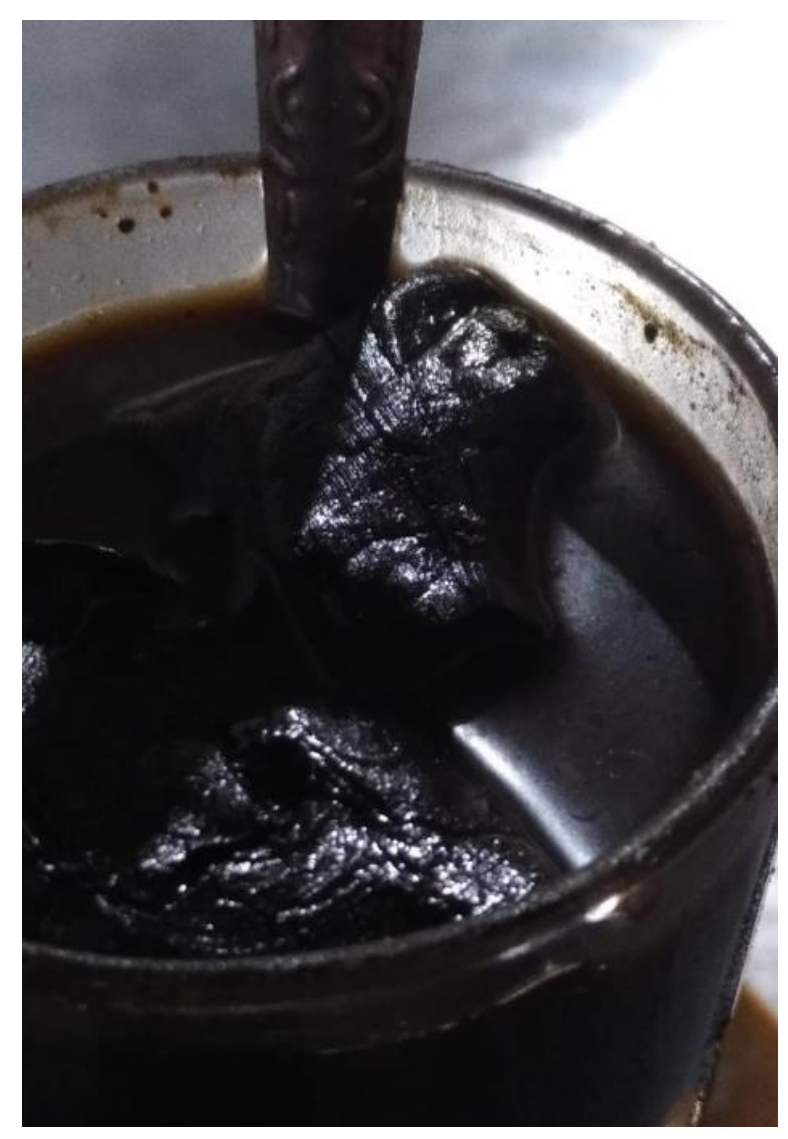

Gambar 1. Kopi Joss yang terkenal dengan penyajiannya yang menggunakan arang Sumber: dokumen pribadi (2020)

Kopi yang digunakan oleh pedagang Kopi Joss yang terkenal di Yogyakarta adalah varietas Kopi Jawa yang berasal dari Klaten, yang disangrai dan ditumbuk sendiri oleh penjual Kopi Joss sampai halus. Air panas yang digunakan untuk menyeduh kopi juga berasal dari air yang direbus dengan ketel - teko besar - yang dipanaskan dengan arang, sehingga memiliki cita rasa yang berbeda. Setelah kopi diseduh dengan air panas, baru kemudian dimulai proses mencelupkan arang panas ke dalam kopi. Manfaat yang didapatkan penikmat kopi selain citarasa asli Yogyakarta, juga bisa mendapatkan manfaat dari zat karbon yang dilepas oleh arang - berfungsi juga sebagai zat penyerap racun yang dapat dibuang melalui saluran pencernaan. Arang terbaik yang digunakan untuk Kopi Joss berasal dari kayu Sambi dari Kalimantan. 
Lokasi warung angkringan yang sangat strategis di daerah dekat Stasiun Yogyakarta, mampu menjadi daya tarik bagi pengunjung dari luar Yogyakarta. Awalnya banyak didatangi oleh mahasiswa, tetapi lama kelamaan banyak didatangi wisatawan domestik maupun dari luar negeri yang sengaja datang ke Yogya untuk mencari Kopi Joss. Bahkan ada komunitas Konco Lawas Angkringan Lik Man, beranggotakan 80 orang yang rutin bertemu, arisan dan ngopi Joss di angkringan ini setiap Minggu malam.

\section{Tujuan Penelitian}

Penelitian tentang bagaimana wisatawan domestik memaknai Kopi Joss, merupakan langkah awal untuk melihat potensi kopi lokal yang dapat dikaitkan dengan pengembangan suatu destinasi dengan potensi pariwisatanya. Beberapa daerah misalnya seperti Toraja sudah terlebih dahulu menjadikan kopinya sebagai sebuah ikon pariwisata. Hal ini dapat menjadi sebuah pijakan untuk melihat potensi kopi-kopi lokal lainnya yang dapat dijadikan sebagai ikon pariwisata di masa yang akan datang.

Berdasarkan hal tersebut di atas, maka penelitian ini ditujukan untuk dapat menjawab pertanyaan bagaimana wisatawan domestik memaknai Kopi Joss sebagai salah satu kopi lokal ketika mengonsumsi kopi tersebut?

\section{Tinjauan Pustaka}

\section{Angkringan}

Angkringan adalah sebutan untuk warung khas yang berasal di Yogyakarta dan biasa dikenal juga dengan istilah warung kaki lima apabila ditempat lain. Ciri khas yang menggambarkannya adalah adanya mobilitas dalam cara berdagangnya dan ditandai dengan menggunakan gerobak sebagai salah satu bentuk atau ciri moda perdagangannya. Angkringan diartikan pula dengan kata angkring atau nangkring yang memiliki pengertian kebebasan atau santai. Salah satu perilaku pembeli yang 
identic dengan kebebasan ini adalah dengan menaikkan satu kakinya keatas bangku tempat dimana mereka makan atau bisa juga dengan melipat kakinya.

Santoso (2014) mengatakan bahwa pedagang angkringan biasanya menjual makanan khas kedaerahan tersebut dan biasanya pada waktu malam hari dengan menggunakan lampu yang berbahan bakar minyak tanah sebagai penerangannya. Biasanya berjualan sejak sore hari dengan rentang waktu yang bisa dari sekitar jam tiga atau lima sore hingga malam hari. Angkringan ini berjualan di trotoar dan menggunakan alas seperti tikar dan didalam tenda menggunakan bangku dan meja yang panjang untuk tempat makan dan minum para pembeli. Peralatan lain yang juga menandakan ciri pedagang asongan adalah kompor arang untuk memasak air dan juga terdapat tiga teko besar.

Jajanan yang terdapat didalam angkringan tersebut adalah nasi yang biasa dikenal sebagai sego kucing dengan lauk pauknya seperti tempe, tahu dan sate usus atau sate telur puyuh. Santoso (2014) juga mendeskripsikan secara jelas bahwa terdapat beberapa peralatan lain seperti tempat sendok, gula dan kopi serta beberapa ember yang digunakan untuk cadangan air yang nantinya akan dimasak dan juga ember yang peruntukkannya untuk mencuci peralatan makan yang kotor. Penelitian lain mendeskripsikan suasana angkringan diungkapkan oleh Azizah (2015) yang mengatakan bahwa terdapat perpaduan antara suasana remang yang dikatakannya eksotis dengan bangku kayu panjang menandai suasana yang tercipta adalah suasananya yang santai yang dirasakan oleh para pengunjung didalam menikmati hiruk pikuk jalan disekitar angkringan tersebut dan harganya yang tergolong murah serta rasanya yang enak. Azizah juga menambahkan bahwa suasana mengobrol atau disebut juga dengan jagongan diiringi dengan bahasan berbagai topik dan diskusi yang terjadi ditempat tersebut. Angkringan merupakan ruang publik masyarakat perkotaan karena partisipasi pengunjung mengutarakan aspirasinya mengenai apa saja yang menjadi daya Tarik mengapa angkringan ini selalu dikunjungi. 


\section{Angkringan sebagai Atraksi Wisata}

Mualifah, dkk (2017) menyatakan bahwa angkringan merupakan suatu simbol kekhasan kuliner Yogyakarta. Konsep angkringan menyuguhkan suatu kesederhanaan, keramahan dan kehangatan yang tetap dimiliki oleh "wong cilik". Semua yang tersaji di angkringan ini lebih memihak pada rakyat kecil. Dalam hal ini keegaliteran angkringan juga ditekankan. Tidak ada perbedaan bagi yang datang ke angkringan. Tidak ada diskriminasi terhadap perbedaan kelas, ras, dan agama. Kebebasan berpendapat dan berkumpul disajikan oleh angkringan sebagai sebuah ruang publik tradisional.

Setiap angkringan biasanya menggunakan tempat atau makanan khasnya sebagai pembeda. Misalnya angkringan angkringan Wijilan, angkringan Sompilan, dan angkringan Tugu. Angkringan Wijilan yang berlokasi di Plengkung Wijilan, yang juga merupakan sentra Gudeg Yogyakarta, menawarkan menu unggulan Es Tape Susu. Angkringan Sompilan yang berada di Ndalem Pakuningratan, Jalan Sompilan Ngasem mengusung tema heritage dalam mengembangkan usaha angkringannya. Berbeda lagi dengan angkringan tugu, angkringan yang berlokasi dekat stasiun Tugu Yogyakarta dengan menu andalan "Kopi Joss".

Penggunaan tempat atau lokasi sebagai pembeda angkringan menggambarkan suatu historical place yang menjadikan angkringan tersebut tidak hanya menjadi pendukung objek wisata lainnya di Yogyakarta, tetapi juga dapat menjadi objek wisata yang mandiri. Bahkan bisa jadi, angkringan selalu menjadi salah satu agenda utama ketika berkunjung ke Jogja. Seperti tergambarkan dalam larik puisi Joko Pinurbo, "Jogja terbuat dari rindu, pulang dan angkringan."

\section{Metafora Konsumsi Ala Holt}

Dalam penelitiannya, Holt (1995) memberikan gambaran mengenai metafora konsumsi yang dapat dilihat dibawah ini. Holt merujuk pada Holbrook (1994) dimana terdapat dua perbedaan dasar didalam konsumsi yaitu struktur konsumsi (structure 
of consumption) dan tujuan konsumsi (purpose of consumption) dimana pada dasarnya konsumsi dilihat sebagai tindakan yang secara langsung melibatkan konsumen dengan objek konsumsi dan interaksinya sebagai sumber daya focus adalah merupakan konsep dasar konsumsi dalam hal struktur. Sementara itu dalam hal tujuan, konsumsi merupakan tindakan konsumen yang bertujuan sendiri dan beberapa tujuan lanjutnya. Dari kedua dimensi konsep dasar konsumsi dapat dianalogikan menjadi 4, yaitu konsumsi sebagai experience (pengalaman), konsumsi sebagai integration (penggabungan), konsumsi sebagai classification (pengelompokan) dan konsumsi sebagai play (permainan).

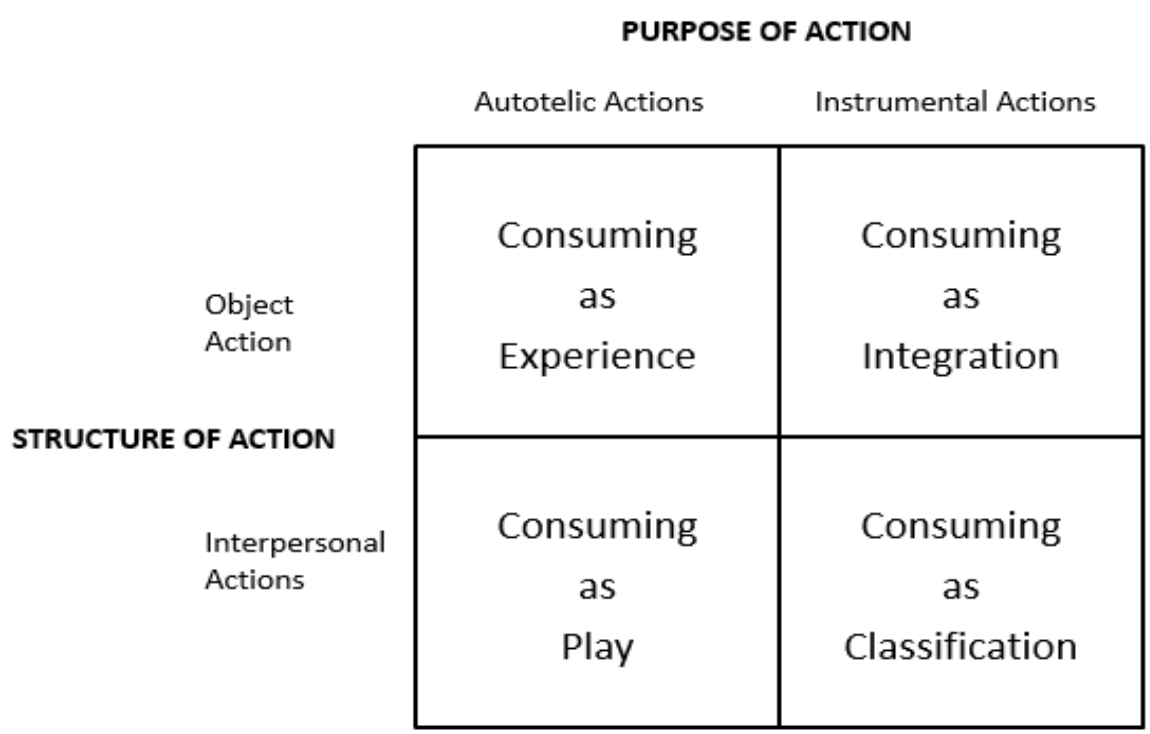

Gambar 2. Holt's Typology

Sumber: Holt (1995)

\section{Konsumsi sebagai Pengalaman (Consuming as Experience)}

Mengacu pada Holt kata kunci yang muncul pada metafora ini adalah reaksi yag bersifat subyektif dan emosiona terhadap objek konsumsi. Pada penelitian yang dilakukan oleh Hirschman konsumsi merupakan fenomena psikologi yang menekankan kondisi emosional saat mengonsumsi objek tertentu. Konsumen menjadi emosional karena dalam proses pencarian pengalaman yang menawarkan unsur 
spektakuler dan ekstravaganza. Nilai fungsional sebuah objek tergantikan oleh aspek sensual dan keinginan memiliki kehidupan yang bervariasi.

\section{Konsumsi sebagai Integrasi (Consuming as Integration)}

Pada kondisi ini terlihat bagaimana konsumen memanipulasi makna dari objek dimana terjadi proses integrasi antara diri (self) dengan objek konsumsi. Beberapa ahli menyatakan bahwa proses ini bisa dikatakan sebagai consumption rituals, proses ekstensi diri (self-extension process), personalizing rituals dan juga proses sakralisasi. Richelieu and Korai (2014) menyebutkan seseorang mengonsumsi untuk hidupnya dengan mengonstruksi identitas diri dan sosialnya.

\section{Konsumsi sebagai Klasifikasi (Consuming as Classification)}

Klasifikasi disini merujuk kepada pendapat yang diutarakan oleh Cova and Cova (2001) dimana interaksi social menjadi begitu dominan dibandingkan dengan produk (objek) itu sendiri. Individu didalam mengonsumsi secara tidak langsung berusaha untuk membuat jejak social (social paths) yang memungkinkan mereka untuk mengekspresikan keinginan mereka untuk terkoneksi atau untuk berinteraksi dengan yang lainnya. (Kleine et al, 2006). Pendapat Curasi (2011) menyatakan adanya keinginan untuk masuk dan keluar dari kelompok tertentu serta memudahkan jalan sosial mereka pada setiap tahapan dalam transisi sosial seseorang memberikan penjelasan terkait bagaimana konsumsi ini dapat dikategorikan untuk menglasifikasikan individu kedalam jejaring sosial mereka.

\section{Konsumsi sebagai Permainan (Consuming as Play)}

Holt sedikit memberikan kekomplekan pada definisi konsumsi sebagai permainan (play) ini karena terkait dengan ketiga kategori konsumsi yang disebutkan diatas. Sebagai aspek penting dalam konsumsi, Holt menekankan pada bagaimana objek konsumsi digunakan oleh seseorang dan relasinya dengan ketiga kategori konsumsi tadi. Richelieu dan Korai (2014 sendiri mencoba untuk menyederhanakan 
kompleksitas definisi ini dengan mengacu pada seperangkat aturan di sekitar objek konsumsi dan keuntungan emosional yang didapatkan sebagai sebuah gratifikasi penghargaan terkait dengan pengalaman konsumsi ini. Meski demikian beberapa pemikir lain, seperti McCracken (1986) misalnya menggambarkan bahwa play ini terkait dengan ritual yang diciptakan dan memiliki reward berupa pengalaman yang berkesan.

\section{Metode Penelitian}

Penggunaan pendekatan kualitatif dianggap mampu menjawab pertanyaan penelitian diatas mengingat bahwa pemaknaan Kopi Joss merupakan sebuah fenomena yang unik dan menarik untuk ditelaah lebih lanjut. Pendekatan kualitatif diharapkan mampu mengeksplorasi pentingnya subjektivitas informan dalam proses penciptaan makna. Miller dan Crabtree (1999) mengatakan bahwa pluralisme menekankan pada adanya fokus akan tegangan yang tercipta antara subyek dan obyek penelitian baik secara dinamis maupun secara sirkular.

Teknik pengumpulan data dilakukan dengan cara observasi dan wawancara mendalam kepada beberapa informan untuk mendapatkan jawaban bagaimana mereka memaknai kopi lokal - Kopi Joss. Penggunaan data sekunder juga tidak menutup kemungkinan dilakukan untuk menambah pemahaman peneliti terhadap penelitian terkait dengan Kopi Joss ini.

Tahapan analisis akan menggunakan Analisis Domain. Analisis Domain merupakan teknis analisis yang dapat digunakan untuk mendapatkan suatu pengetahuan budaya yang disebut juga sebagai domain. Analisis ini mencari simbol kultur yang didasarkan pada pembuatan kategori yang lebih besar berdasarkan persamaan. Dalam penelitian ini identifikasi domain dapat dibantu dengan menggunakan semantic relationship. Hal ini dilakukan karena makna dalam suatu budaya tertentu akan sangat tergantung dari relasi antar simbol yang dapat dilihat 
dari penggunaan konsep dari hubungan-hubungan ini yang nantinya akan membentuk sebuah kode dari simbol-simbol tersebut.

Berdasarkan penelitian yang dilakukan oleh Spradley (1979) terdapat semantic relationship yang dapat digunakan untuk melakukan sebuah analisis domain seperti yang tertera dibawah ini:

Tabel 1. Hubungan Semantik

\begin{tabular}{|l|l|}
\hline Hubungan Semantik & Bentuk \\
\hline Jenis & X adalah jenis dari Y \\
\hline Ruang & X adalah tempat YY adalah bagian dari Y \\
\hline Sebab Akibat & X adalah akibat/hasil dari YX adalah sebab dari Y \\
\hline Rasional & X merupakan alasan melakukan $Y$ \\
\hline Lokasi untuk melakukan & X merupakan tempat melakukan Y \\
\hline Fungsi & X digunakan untuk Y \\
\hline Cara ke tujuan & X adalah cara untuk melakukan Y \\
\hline Urutan & X merupakan urutan atau tahapan \\
\hline Atribut atau Karakter & X merupakan sebuah atribut/karakteristik dari Y \\
\hline
\end{tabular}

Sumber: Spradley (1979, p 116)

\section{Analisis Dan Pembahasan}

Pembahasan Kopi Joss dari sudut pandang merek menjadi menarik, khususnya dari proses penciptaan tanda yang memiliki kemudian diberikan makna oleh para penikmat kopi tersebut. Studi yang dilakukan oleh Kleidas dan Jolliffe (2010) menemukan bahwa wisatawan kopi memaknai pengalaman dalam proses pencarian, penyeduhan dan penyajian kopi. Disamping kualitas kopi, asal muasal, variasi rasa, dan cara penyajian menjadi sangat penting bagi mereka. 
Kajian menarik yang dilakukan oleh Franzen dan Bowman (2001) yang melihat empat faktor yang membentuk pemakanaan kopi joss di benak konsumen yakni: (1) nama dan kemasan; (2) atribut produk; (3) asosiasi simbolik dan konsekuensinya; dan (4) organisasi asosiasi termasuk di dalamnya terkait asal mula dan kompetensi. Keempat ini hal ini menjadi serangkaian persyaratan untuk menelaah lebih dalam terkait makna yang dihasilkan dari Kopi Joss sebagai fokus penelitian.

Makna menjadi penting apabila dilihat dari proses terciptanya makna itu sendiri. Pada proses penciptaan makna terdapat hubungan antara objek dan individu. Pedagang Angkringan Kopi Joss dianggap mampu melihat adanya potensi didalam melakukan sebuah aktivitas penciptaan makna. Dari sudut pandang pengunjung, makna yang dirasakannya terjadi sebagai aktivasi terhadap tanda itu sendiri yang dalam hal ini adalah Kopi Joss.

Sementara Verma (2013) menyebutkan bahwa setiap konsumsi memiliki makna kultural, sehingga merek dalam hal ini secara strategis memiliki posisi di dalam benak konsumen secara multidimensional dari sisi tempat (space). Sebagai contoh dalam kategorisasi kopi, misalnya Kopi dianggap sebagai minuman "luar" yang memiliki perbedaan dengan teh yang digambarkan sebagai minuman "dalam". Kata "dalam" disini diartikan bahwa teh menempati posisi di dalam rumah berbeda dengan kopi yang secara konteks lebih cenderung diasosiasikan sebagai "minuman luar rumah" sehingga implikasinya adalah kopi - secara instrumen sosial - dikatakan identik dengan dunia luar dimana tempat (space) tersebut diasosiasikan dengan orang asing (strangers), agresi dan juga perasaan yang tidak pasti (insecurities).

Kopi juga memiliki peran sebagai fasilitator dalam konteks membangun hubungan baik dengan orang asing atau hubungan dengan pencipta dan pemupuk hubungan atau "bonding." Kombinasi strangers dan "luar rumah" tadi mengantarkan kopi sebagai instrumen sosial yang menjadi sinyal tentang identitas 
diri, kedudukan sosial dalam masyarakat, rasa yang kita inginkan, dan bagaimana kita ingin diperlakukan.

Dalam artikelnya, Verma juga memberikan model pertentangan antara kopi dan teh. Namun untuk kepentingan riset ini, model Verma dimodifikasi agar lebih menekankan pada sisi konteks, makna dan instrumental dari kopi yang dapat digunakan juga untuk membantu menganalisis mengenai Kopi Joss. Berikut gambaran model tersebut:

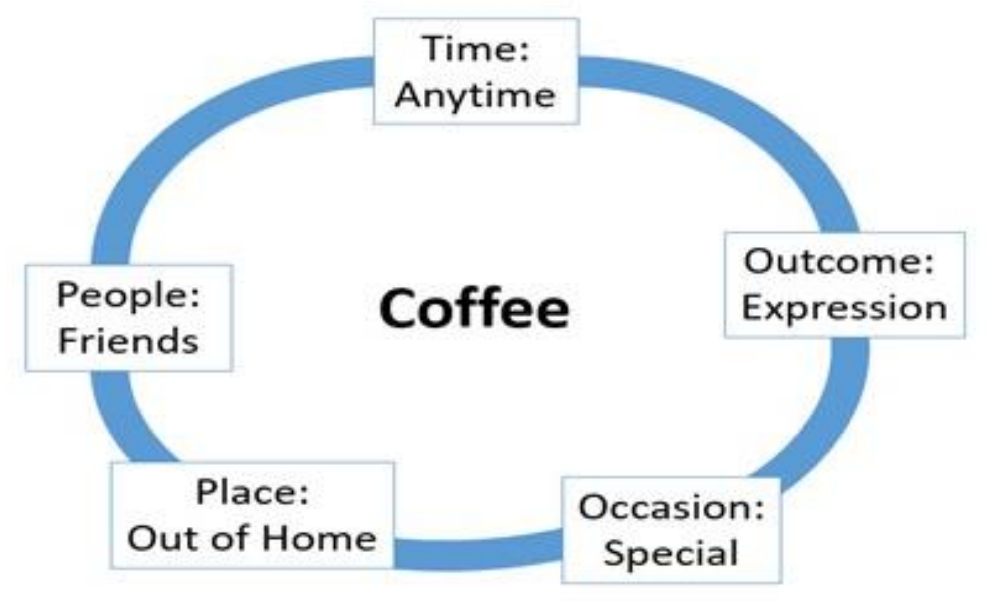

Gambar 3. Context, Meaning and Instrumentality of Coffee Sumber: modifikasi Verma (2013)

Didalam proses mencari makna Kopi Joss berikut adalah penggolongan yang dilakukan dengan menggunakan analisis domain seperti berikut.

Dalam Kopi Joss, "keramaian" didalam angkringan Kopi Joss ternyata memiliki pendapat yang berbeda. Dimana disatu sisi antri yang ramai yang juga diidentikkan dengan berisik dan pengamen yang datang. Hal tersebut dapat mempengaruhi emosi pengunjung sehingga menjadikannya malas untuk berada disana.

"karena kalo misalnya yang rame sih, ngantri sih, lama sebenernya, Cuma kan kalo rame... berisik gituloh terus sering dikunjungin pengamen, itu yang bikin males." 


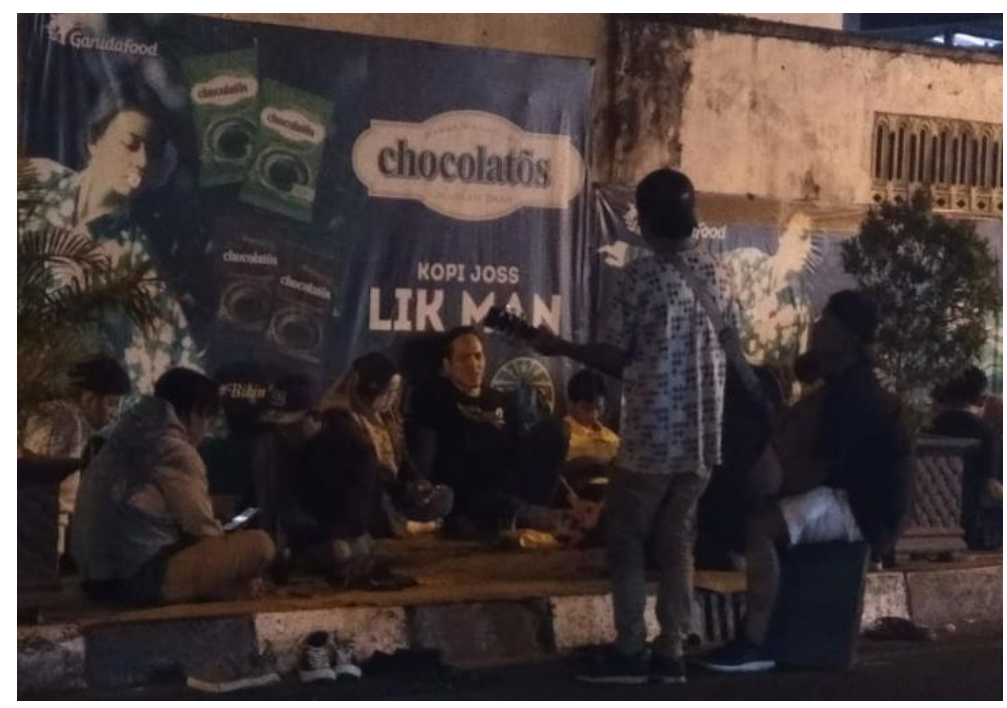

Gambar 4. Keberadaan Pengamen pada saat ramai pengunjung Kopi Joss Sumber: dokumen pribadi (2020)

Pendapat yang lain terkait dengan keramaian di angkringan Kopi Joss. Persepsi ramai selalu dikaitan dengan sajian minuman kopi yang enak menjadi anggapan yang seringkali beredar pada konteks masyarakat kita terutama pada bisnis yang terkait dengan makanan dan minuman sehingga ramai memiliki makna positif di mata pengunjung.

"iya yang rame soalnya biasanya enak sih"

\section{Keunikan Kopi Joss}

Keunikan Kopi Joss menjadi salah satu mengapa pengunjung memilihnya dibandingkan dengan minuman lainnya. Dari beberapa pendapat dapat disarikan bahwa keunikan Kopi Joss dapat diidentifikasi memiliki keunikan-keunikan yang dirasakan oleh pengunjung yang dikategorikan sebagai wisatawan domestik

Kopi Joss dilihat unik karena terdapat unsur atraksinya yaitu pada saat arang yang membara kemudian ditaruh kedalam gelas kopi sehingga menjadikannya sebagai minuman yang unik yang berasal dari Jogjakarta. Disamping keunikan dari arang yang dimasukkan kedalam kopi, harga yang murah menjadi paket pelengkap 
dari atraksi minum kopi unik tersebut. Berikut petikan pendapat seseorang terkait dengan hal tersebut:

"Kopi Joss dari Jogja, unik, murah harganya murah meriah dia dimasukin arang jadi itu yang membuat dia unik dan membuat dia booming ke orang orang lain. Jadi ya itu yang membuat dia unik itu arang yang membara yang di taro di kopi itu yang bikin dia unik" "Pertama kan dari yang saya bilang dari penyajiannya pakai arang. Yang kedua dari teksturnya mungkin ya. Kalau kopi lain yang memang kopi jenisnya kering dia kan bisa begitu dihirup langsung abis. Atau kopi yang berampas dia masih ada ampasnya. Ini masih ada arangnya Mba. Nah arangnya itu bisa dipakai lagi untuk 2 sampai 3 kali seduhan.

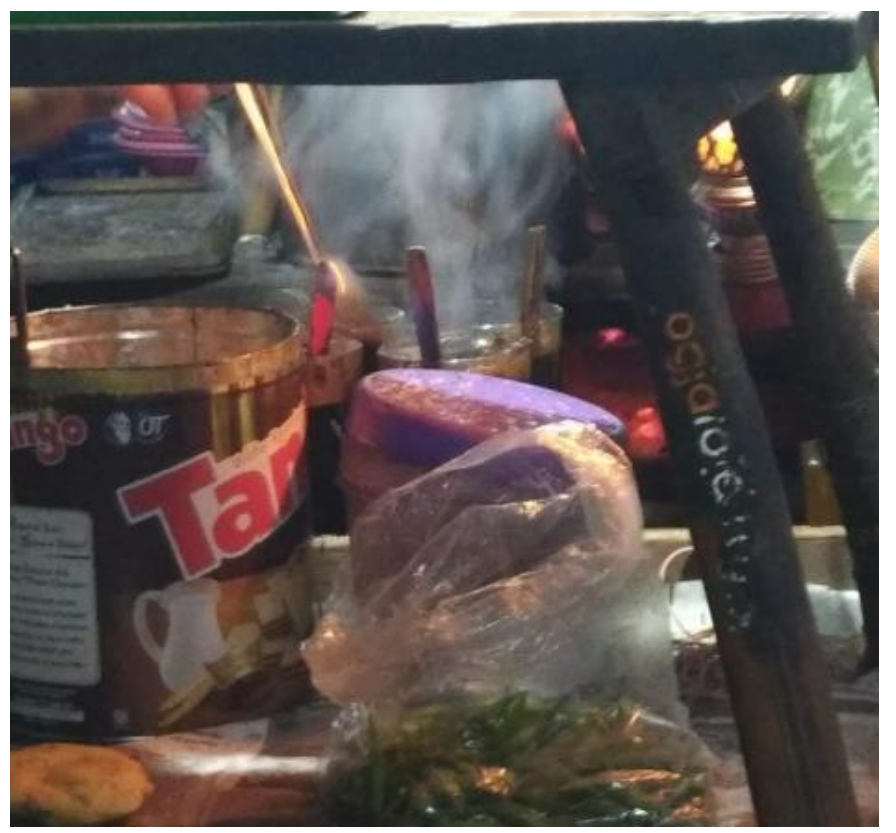

Gambar 5. Keunikan Kopi Joss pada saat dimasukkan arang Sumber: dokumen pribadi (2020)

Seperti yang dijelaskan oleh Verma, Kopi Joss juga memiliki asosiasi tempat yang sangat kuat. Letaknya yang dekat daerah yang biasa dikunjungi oleh wisatawan membuat Kopi Joss memiliki keterkaitan dengan "tempat" seperti Jalan Malioboro, angkringan, lesehan. Seperti yang dikemukakan oleh beberapa informan dibawah ini: 
"Deket Malioboro situ sih. Di angkringan-angkringan situ ya."

"Lesehannya begitu sih tapi disebrang jalan tapi itu masih punya Lekman."

Keunikan lain Kopi Joss adalah terkait dengan "sensasi" yang dirasakan oleh para pengunjung kopi tersebut. Tidak mengherankan apabila dalam konteks konsumsi pengalaman yang lebih fokus pada reaksi yang bersifat subyektif dan emosional terhadap Kopi Joss. Penekanan pengalaman pada proses pencarian dalam Kopi Joss ini adalah terkait dengan unsur spektakuler atau ekstravaganza seperti yang diutarakan oleh Holt.

Dalam kasus Kopi Joss sensasi menjadi hal yang spektakuler tersebut yang dirasakan dari menikmati kopi tersebut yang memungkinkan memiliki kehidupan yang variatif yang didapatkan karena berdasarkan rasionalisasi pengunjung ada unsur keseimbangan baik dari sisi manis dan pahit yang didapatkan karena adanya fitur arang didalam Kopi Joss tersebut. Arang memiliki fungsi menetralkan dan membuat pengunjung ingin selalu merasakan Kopi Joss kembali karena tidak menemukan pengalaman serupa dalam menikmati sebuah kopi. Beberapa pendapat dapat dilihat dibawah ini:

"Bersama dengan arang didalamnya. Nah tapi setelah nikmatin dari teguk ketegukannya itu ada sensasi yang beda. Panasnya pas. Dari manisnya pas.Dari pahitnya pas. Lalu dari suasananya juga yang mendukung biasanya sensasi Kopi Joss Manisnya itu arangnya itu justru malah penetral pahit dan manisnya. Jadi imbang." 


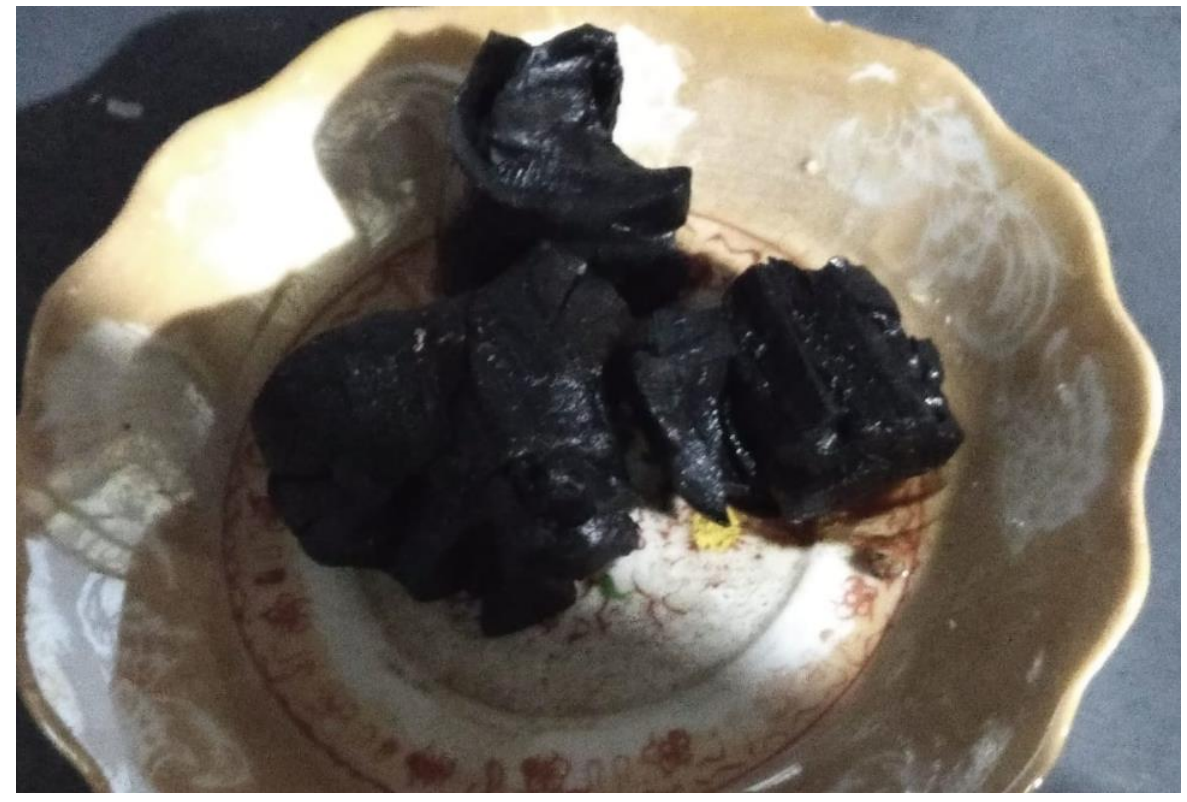

Gambar 6. Arang Sebagai Penetral

Sumber: dokumen pribadi

"Antara manis sama pahitnya itu setara. Sebanding gitu. Karena dinetralkan sama pahitnya arang tadi. Arang kan warnanya hitam tuh."

"Saya rasa ini unik... Kopi yang dicampur dengan arang. Bahkan orang luar negeri pun agak aneh gitu lihatnya. Tapi begitu mereka sudah nikmatin... Ya justru malah ketagihan"

Verma menambahkan dalam penelitiannya terdahulu bahwa kopi secara kultural juga memiliki pengertian sebagai minuman luar rumah juga memiliki peran sebagai fasilitator dalam konteks hubungan. Hal senada juga ditemukan dalam kajian mengenai Kopi Joss ini. Makna hubungan didalam Kopi Joss ini lebih menekankan pada unsur "kebersamaan" yang lebih kelihatan apabila dilihat dari beberapa pendapat informan dibawah ini:

"Saya lebih bisa menikmati ngopi itu bareng sama temen-temen. Karena disaat itu ada obrolan-obrolan ga penting tapi terlepaskan atau tersampaikan kepada teman-teman."

"Saya percaya bahwa tawa itu bisa menular. Saya percaya bahwa hobi kesukaan itu bisa menular...Itu saya percaya. Jadi ketika memang kita uh..bersantai bersama ada salah satu yang mesen kopi pasti akhirnya dia juga nawarin." 


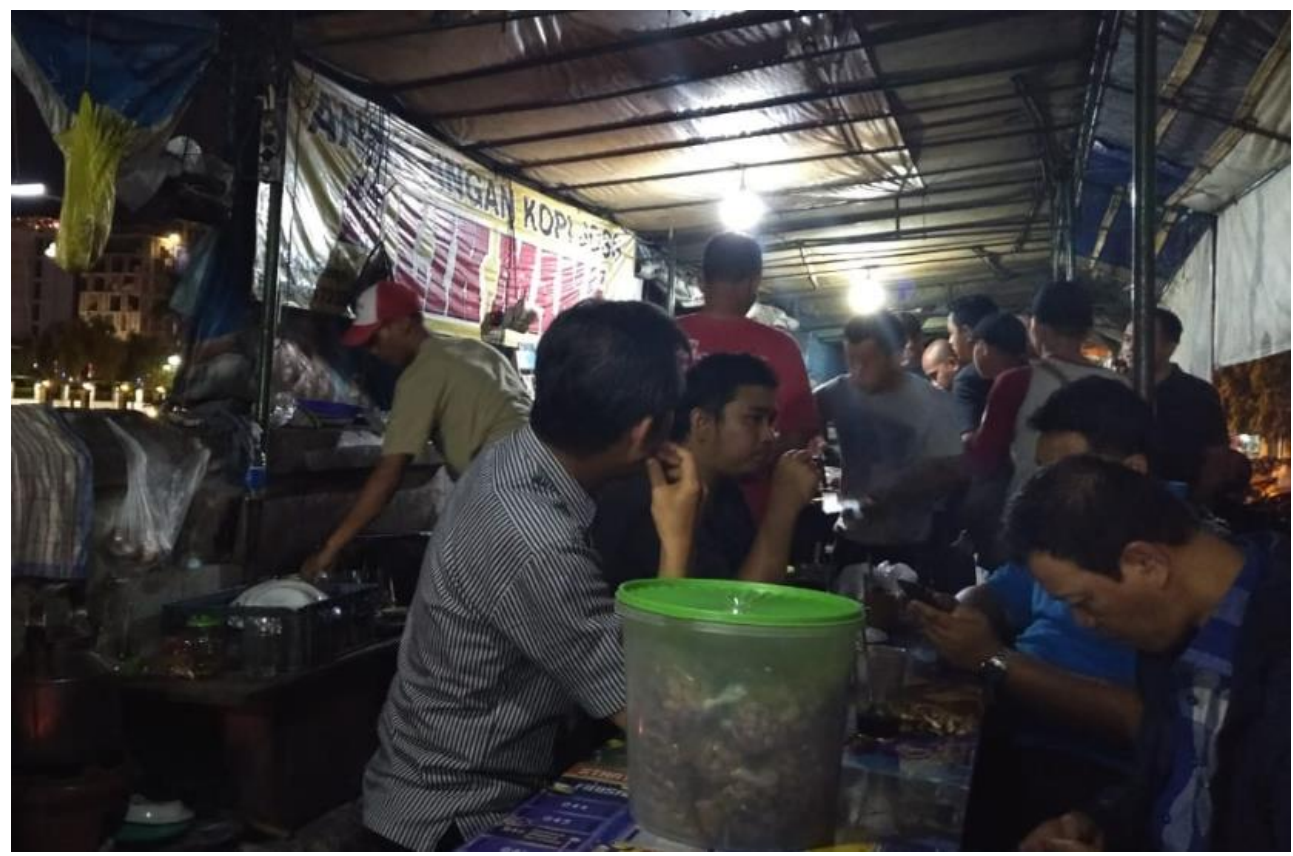

Gambar 7. Kopi Joss adalah kebersamaan

Sumber: dokumen pribadi (2020)

Namun yang menarik, juga mengaitkan Kopi Joss ini dengan perasaan bernostalgia dengan kenangan individu. Mengingat tempat kelahiran karena merasakan suasana

"Nah itu ciri khas nya apa ya nambahin momen saya untuk nginget tempat kelahiran. Jadi tanpa terasa saya bisa merasakan momen dimana tempat kampung halaman saya."

\section{Kesimpulan}

Dari hasil pencarian makna dari Kopi Joss ini, paling tidak beberapa temuan dari hasil penelitian ini menunjukkan bahwa Kopi Joss memiliki beberapa makna yang menjadi krusial karena begitu kuat tertanam di benak pengunjung yang dalam hal ini adalah wisatawan domestik.

Beberapa atribut pokok terkait fitur standar layaknya kopi yang biasa menjadi sesuatu yang memang menggambarkan kopi dengan karakteristik seperti orisinalitas yang berasal dari Kota Yogyakarta dan harga yang dianggap murah namun tidak murahan apabila mengacu pada pengalaman yang didapatkan oleh pengunjung. 
Kopi Joss dimaknai sebagai kopi yang memiliki diferensiasi dengan kekuatan pada konsumsi pengalaman yang kuat dari sisi sensasi dan nostalgia yang begitu kuat. kopi Joss dapat menggunakan kekuatan asosiasi yang kuat ini sebagai salah satu yang dapat dijadikan sebagai penguat posisi Kopi Joss untuk kedepannya agar tetap eksis dan lestari.

\section{Daftar Pustaka}

Azizah, R. 2015. Angkringan sebagai Unsur Tradisional tempat Interaksi Sosial Masyarakat Perkotaan (Studi Deskriptif Analisis di Kecamatan Pamulang Kota Tangerang Selatan), UIN, Jakarta.

Holt, D. B. 1995. How Consumers Consume: A Typology of Consumption Practices. Journal of Consumer Research.

McCracken, G. 1986. Culture and Consumption: A Theoretical Account of the Structure and Movement of the Cultural Meaning of Consumer Goods. Journal of Consumer Research, 13, 71-84.

Santoso, S. 2014. Pola Solidaritas Kelompok Pedagang Angkringan di Kota Ponorogo. Sosiohumaniora, 16(1), 62-69.

Verma, H. V. 2013. Coffee and Tea: Socio-cultural Meaning, Context and Branding. Asia-Pacific Journal of Management Research and Innovation, 9(2), 157-170.

Spradley, J.P. 1979, the ethnographic interview Interview (H.B. JC, Publisher, Ed) New York, NY.

Mualifah, dkk. 2017." Angkringan Sebagai Simbol Keramahan Wisata Kuliner di Yogyakarta" dalam Murdiyastomo (Ed). Budaya Lokal dalam Perkembangan Pariwisata di Yogyakarta. Yogyakarta: Penerbit Ilmu Sejarah FIS UNY.

https://databoks.katadata.co.id/datapublish/2019/07/03/jumlah-perjalananwisatawan-nusantara-2018-tumbuh-12.

\section{Profil Penulis}

Yudo Hartono adalah Ketua Program Studi Pariwisata di Universitas Prasetiya Mulya, pengajar di beberapa mata kuliah seperti Consumer Behavior in Hospitality and Tourism, Creative and Design Thinking dan Experience Design. Ia merupakan 
pemrakarsa tim pengabdian masyarakat khususnya terkait dengan ekplorasi potensi wisata di desa binaan yang diadakan oleh Universitas Prasetiya Mulya. Yudo juga menjadi anggota delegasi beberapa institusi pendidikan Indonesia yang bekerjasama dengan beberapa institusi Pendidikan di Swiss serta menjadi salah seorang anggota Senior Asia Pacific Institute for Event Management. Disamping itu, ia juga aktif dalam beberapa asosiasi seperti menjadi salah satu Pendiri dan Pengurus Asosiasi Peneliti Jaringan Sosial Indonesia, menjadi anggota Asosiasi Peneliti Pariwisata Indonesia, serta menjadi anggota dalam Forum Akademisi BUMDES. Yudo terlibat secara aktif sebagai kontributor pada beberapa media nasional terkait bidang pariwisata serta menjadi co-author dalam beberapa buku seperti Social Media Nation, Sari-sari Pemasaran dan lain-lain. keaktifannya dalam berdiskusi terkait dengan pariwisata mengantarkannya menjadi narasumber dibeberapa forum dan menjadi tenaga ahli dalam kemitraan bidang industri di Kementerian Pariwisata dan Ekonomi Kreatif Indonesia.

Sri Widya Wijanarti adalah Manager Program S1 Hospitality Business di Universitas Prasetiya Mulya, pengajar di beberapa mata kuliah seperti Food and Beverage Operation, Food and Beverage Management, Food and Beverage Business, Coffee Business and Management, dan Revenue Management. Beliau aktif didalam perencanaan dan pembangunan laboratorium penunjang proses pembelajaran di program studi Pariwisata seperti Kitchen Lab dan Dry Mock Up Room Lab. Disamping itu ia juga berperan sebagai perancang Mata Kuliah Pilihan Coffee Business and Management di S1 Business, yang merupakan kolaborasi antara Jurusan S1 Business dan S1 Hospitality Business. Selain itu, Widya juga aktif menuliskan pemikiran dan analisisnya di bidang Kuliner untuk Majalah Bisnis internal yang diterbitkan oleh Prasetiya Mulya. 